\title{
PENGARUH BUDAYA KERJA DAN PELATIHAN TERHADAP KINERJA PEGAWAI PADA PT. BLUE BIRD POOL JAKARTA TIMUR
}

\author{
Styo Budi Utomo \\ Staf Pengajar Fakultas Ekonomi Universitas Pamulang \\ email: dosen01759@unpam.ac.id
}

\begin{abstract}
ABSTRAK
Tujuan dari penelitian ini adalah Untuk mengetahui pengaruh budaya kerja secaara parrsial terrhadap kiinerja karyawan pada PT. Blue Bird Pool Jakarta Timur. unntuk mengetahui pengaruh secara parsial antara pelatihan terrhadap kinerja karyawan pada PT. Blue Bird Pool Jakarta Timur, untuk mengetahui pengaruh secara simultan antara budaya kerja dan pelatihan terhadap kinerja karyawan pada PT. Blue Bird Pool Jakarta Timur. Metode dalam penelitian adalah dengan menggunakan regresi linier berganda, dengan tahapan uji asumsi klasik (normalitas data, multikolinearitas dan heteroskedastisitas), koefisien determinasi, analisis koefisien regresi linier berganda dan uji signifikan ( $\mathrm{t}$ dan $\mathrm{F}$ ). Data yang digunakan adalah data primer dengan cara membagikan kuesioner kepada responden yaitu karyawan pada PT. Blue Bird Pool Jakarta Timur yang berjumlah 50 karyawan. Hasil penelitian menunjukan bahwa bahwa secara parsial variabel budaya kerja dan pelatihan berpengaruh terhadap kinerja karyawan. Secara simultan juga menunujukkan bahwa variabel budaya kerja dan pelatihan berpengaruh terhadap kinerja karyawan. Berdasarkan hasil koefisien determinasi ditemukan bahwa variabel budaya kerja dan pelatihhan memiliki pengaruh sebesar 78\%, sedangkan sisanya $22 \%$ dijelaskan dengan faktor atau variabel lain yang tidak diketahui dan tidak termasuk dalam analisis regresi ini, seperti budaya organisasi, lingkungan kerja dan lain-lain.
\end{abstract}

Kata kunci: budaya kerja, pelatihan, kinerja karyawan.

\section{ABSTRACT}

The purpose of this research is to know the influence of the culture of working Secaara parrsial of the employee Kiinerja at PT. Blue Bird Pool East Jakarta. Air knows the partial influence between the performance of the employee in PT. Blue Bird Pool East Jakarta, to know the simultaneous influence between working culture and training on employee performance at pt. Blue Bird Pool Jakarta East. The method in the study is to use multiple linear regression, with the classical test stage (normality of data, multicolinearity and heteroskedastisity), coefficient of determination, analysis of double linear regression coefficient and test Significant ( $T$ and $F$ ). The data used is primary data by distributing questionnaires to respondents that are employees at PT. Blue Bird Pool East Jakarta, amounting to 50 employees. The results showed that a partial variable of occupational culture and training affected the employee's performance. It also shows that working culture and training variables affect employee performance. Based on the results of the coefficient of determination found that the working and training culture variables have an influence of $78 \%$, while the remaining $22 \%$ is explained by other unknown factors or variables that are not included in this regression analysis, Such as organizational culture, working environment and others.

Keywords: work culture, training, employee performance. 


\section{PENDAHULUAN}

\section{A. Lattar Beelakang}

Setiap perencanaan yang dibuat harus memiliki arah dan tujuan yang jelas sehingga dapat dengan optimal mewujudkan kemajuan bagi negara. Dalam lingkup suatu negara tentu banyak bidang yang harus diperhatikan, seperti bidang sumber daya alam, sumber daya manusia, pendidikan, kebudayaan, ekonomi, ketenagakerjaan, sosial dan kemasyarakatan, serta sarana dan prasarana. Semua bidang tersebut membutuhkan perhatian yang serius dan kontinu dalam hal perencanaannya sehingga dapat menciptakan kemajuan bagi Negara.

Semakin berkembangnya zaman maka permasalahan yang dialami sebuah negara kian kompleks. Hal ini mengharuskan pemerintah dan semua elemen masyarakat bersinergi untuk bisa menyelesaikan permasalahan tersebut. Dalam hal ini peran perencanaan sangat dibutuhkan, supaya nantinya pembangunan yang akan dilaksanakan akan berdampak secara nyata dan dapat mengatasi permasalahan-permasalahan yang ada.

Pemerintah dalam menyusun rencana pembangunan membentuk suatu lembaga pemerintah nonkementerian yang bernama Badan Perencanaan Pembangunan Nasional (Bappenas). Kedudukan Bappenas sangat penting karena memiliki tugas utama yakni mengkaji, mengkoordinasi, dan merumuskan kebijakan di bidang perencanaan pembangunan nasional sesuai dengan ketentuan peraturan perundangundangan. Adapun dua peran utama dari Bappenas, yaitu pertama berperan dalam menjaga keberlangsungan sistem perencanaan pembangunan nasional. Amanat peran tersebut tertuang dalam peraturan perundang-undangan, yaitu (i) Undang-Undang No. 25 Tahun 2004 tentang Sistem Perencanaan Pembangunan Nasional (SPPN); (ii) Peraturan Presiden
(Perpres) Nomor 7 Tahun 2015 tentang Organisasi Kementerian Negara; (iii) Perpres Nomor 65 Tahun 2015 tentang Kementerian Perencanaan Pembangunan Nasional (PPN); (iv) Perpres Nomor 66 Tahun 2015 tentang Badan Perencanaan Pembangunan Nasional (Bappenas) sebagaimana telah diubah dengan Perpres Nomor 20 Tahun 2016. Dan kedua berperan dalam mensinergikan perencanaan di tingkat pusat dan daerah untuk mengarahkan pelaksanaan pembangunan oleh pemerintah pusat dan pemerintah daerah, sehingga dalam pelaksanaannya dapat saling memperkuat dan mempercepat dalam pencapaian target yang diinginkan.

Sehubungan dengan hal tersebut, Bappenas memiliki tugas pokok dan fungsi seperti yang telah tertuang dalam Perpres Nomor 65 Tahun 2015 tentang Kementerian Perencanaan Pembangunan Nasional, tugas Kementerian PPN adalah menyelenggarakan urusan pemerintah di bidang perencanaan pembangunan nasional untuk membantu Presiden dalam menyelenggarakan pemerintahan negara. Sedangkan fungsi Kementerian PPN berdasarkan Perpres Nomor 65 Tahun 2015 adalah:

1. Perumusan dan penetapan kebijakan di bidang perencanaan pembangunan nasional, strategi pembangunan nasional, arah kebijakan sektoral, lintas sektor, dan lintas wilayah, serta kerangka ekonomi makro yang mencakup gambaran perekonomian secara menyeluruh termasuk arah kebijakan fiskal, kerangka regulasi, kelembagaan, dan pendanaan;

2. Koordinasi dan sinkronisasi pelaksanaan kebijakan di bidang perencanaan dan penganggaran pembangunan nasional;

3. Pembinaan dan pemberian dukungan administrasi kepada seluruh unsur organisasi di lingkungan Kementerian Perencanaan Pembangunan Nasional; 
4. Pengelolaan barang milik/kekayaan negara yang menjadi tanggung jawab Kementerian rencanaan Pembangunan Nasional.

5. Pengawasan atas pelaksanaan tugas di lingkungan Kementerian Perencanaan Pembangunan Nasional.

Keberhasilan penyusunan kebijakan dalam rangka merencanakan pembangunan sangat bergantung pada aspek pemberdayaan sumber daya manusia. Oleh karenanya, aspek sumber daya manusia menjadi hal utama yang perlu diperhatikan mengingat kedudukan dan peran pegawai negeri sebagai aparatur negara yang berperan sebagai abdi masyarakat harus dapat melaksanakan tugasnya secara optimal. Lebih jauh lagi bahwa pegawai negeri sebagai unsur aparatur negara yang melaksanakan pemerintahan dan pembangunan dalam usaha mencapai tujuan nasional. Dengan demikian pegawai negeri dituntut untuk memiliki kemampuan, loyalitas dan integritas dalam menjalankan tugas dan tanggung jawabnya untuk berpartisipasi dalam kegiatan pemerintahan, pembangunan serta kemasyarakatan secara efektif dan efisien.

Demi tercapainya kinerja pegawai negeri yang berkualitas dan sejalan dengan tujuan dari Bappenas, maka diperlukan adanya budaya organisasi dan budaya kerja yang baik, sehingga dengan budaya tersebut dapat menjadi kekuatan dan penggerak dalam pencapaian tujuan organisasi. Hal ini dikarenakan budaya organisasi merupakan segala hal yang mengacu kepada sistem makna bersama yang dianut oleh anggota-anggota yang membedakan organisasi itu dari organisasi-organisasi lain. Sistem makna bersama ini bila diamati dengan lebih seksama merupakan seperangkat karakteristik utama yang dihargai oleh organisasi itu.

Sedangkan budaya kerja itu sendiri merupakan suatu falsafah dengan didasari pandangan hidup sebagai nilai-nilai yang menjadi sifat, kebiasaan dan juga pendorong yang dibudayakan dalam suatu kelompok dan tercermin dalam sikap menjadi perilaku, cita-cita, pendapat, pandangan serta tindakan yang terwujud sebagai kerja. (Supriyadi, 2015:8)

Berdasarkan penjelasan tersebut, maka kita dapat menarik kesimpulan bahwa budaya organisasi lebih berorientasi kepada nilai dan norma yang mendasari keseluruhan perilaku anggota dalam organisasi. Sedangkan budaya kerja lebih menekankan pada apa yang harus dikerjakan dan bagaimana melakukan pekerjaan tersebut, juga mengacu pada etika dalam melakukan sebuah pekerjaan. Budaya kerja sendiri dapat dikatakan sebagai kebiasaan yang seharusnya dilakukan anggota organisasi dalam melakukan pekerjaan sehari-hari.

Faktor lain yang juga berpengaruh terhadap kinerja pegawai negeri adalah pelatihan. Hal ini dikarenakan pelatihan merupakan sebuah upaya untuk memperbaiki penguasaan berbagai keterampilan dan teknik pelaksanaan kerja tertentu, terinci, dan rutin.

Penelitian ini akan dilakukan pada PT. Blue Bird Jakarta Timur, PT. Blue Bird merupakan perusahaan yang bergerak di bidang jasa transportasi, tidak dapat terhindar dari perubahan bisnis yang semakin memungkinkan persaingan secara terbuka di dalam berbagai sektor. PT. Blue Bird dituntut untuk lebih memperhatikan aspek sumber daya manusia (SDM) yang dimilikinya untuk dapat menciptakan karyawan yang profesional, tangguh, cekatan, cerdas, dan berpandangan ke depan. Karyawan sebagai sumber daya yang paling berharga yang dimiliki PT. Blu Bird diharapkan dapat memberikan kontribusi yang besar terhadap kemajuan PT. Blue Bird dalam menghadapi persaingan (Wawancara, PT. Blue Bird Pool Jakarta Timur).

Berdasarkan hasil wawancara dengan Unit Manajer pada PT. Blue Bird Pool Jakarta Timur dalam kaitannya 
dengan motivasi yang diberikan kepada karyawan, menyatakan bahwa bentuk pemberian motivasi yang diberikan pada karyawan dapat berupa insentif, bonus, dan lain-lain. Dimana pemberian tersebut hanya diberikan kepada karyawan yang berprestasi saja, tidak untuk semua karyawan. Hal itu tidak sesuai dengan kenyataannya, pemberian tersebut tidak membuat dampak yang cukup berarti bagi karyawan untuk meningkatkan motivasinya karena karyawan beranggapan bahwa pemberian insentif tersebut diberikan bergilir kepada setiap karyawan dan setiap karyawan pasti mendapatkannya (Wawancara, PT. Blue Bird Pool Jakarta Timur).

Maka dari itu berdasarkan latar belakang masalah yang telah dikemukakan tentang kinerja aparatur negara yang belum optimal dan hubungannya dengan budaya organisasi, budaya kerja, dan pelatihan sehingga penulis tertarik untuk mengkaji lebih dalam tentang PENGARUH BUDAYA KERJA DAN PELATIHAN TERHADAP KINERJA PEGAWAI PADA PT. BLUE BIRD POOL JAKARTA TIMUR”.

\section{B. Perumusan Masalah}

Berdasarkan permasalahan tersebut maka penulis dalam penelitian ini memiliki rumusan masalah sebagai berikut:

1. Apakaah budaya kerja berpngaruh secaara parrsial terrhadap kiinerja karyawan pada PT. Blue Bird Pool Jakarta Timur?

2. Apakaah pelatihan berpngaruh secara parsial terrhadap kinerja karyawan pada PT. Blue Bird Pool Jakarta Timur ?

3. Apakah budaya kerja dan pelatihan berpengaruh secara simultan terhadap kinerja karyawan pada PT. Blue Bird Pool Jakarta Timur?

\section{Tujuan Penelitian}

Penelitian ini bertujuan untuk menguji dan menganalisis proses kegiatan yang dilakukan di PT. Inkabiz Indonesia, yaitu:

1. Untuk mengetahui pengaruh budaya kerja secaara parrsial terrhadap kiinerja karyawan pada PT. Blue Bird Pool Jakarta Timur.

2. Unntuk mengetahui pengaruh secara parsial antara pelatihan terrhadap kinerja karyawan pada PT. Blue Bird Pool Jakarta Timur.

3. Untuk mengetahui pengaruh secara simultan antara budaya kerja dan pelatihan terhadap kinerja karyawan pada PT. Blue Bird Pool Jakarta Timur.

\section{TINJAUAN PUSTAKA}

\section{A. Manajemen}

Manajemen berasal dari kosa kata bahasa Perancis kuno, yaitu menegement berarti seni melaksanakan dan mengatur. Pengertian manajemen dari para ahli memiliki beberapa perbedaan namun maksud dan tujuannya sama .

"Manajemen adalah ilmu dan seni mengatur, memanfaatkan sumber daya manusia dan sumber daya lainnya secara efektif dan efisien untuk mencapai suatu tujuan tertentu menurut SP. Hasibuan (2010:2)".

"Manajemen adalah proses untuk mencapai tujuan-tujuan organsiasi dengan melakukan kegiatan dari empat fungsi utama yang merencanakan (planning), proses mengorganisasian (organizing), memimpin (leading) dan proses mengendalikan (controlling). dengan demikian, manajemen adalah suatu kegiatan yang berkesinambungan.

Pengertian manajemen (Handoko, 2015:8) menjelaskan bahwa "manajemen adalah proses perencanaan, pengorganisasian, pengarahan dan pengawasan usaha-usaha para anggota organisasi dan penggunaan sumber dayasumber daya organisasi lainnya agar mencapai tujuan organisasi yang telah ditetapkan".

"Manajemen sebagai proses yang khas, yang terdiri atas tindakan-tindakan 
perencanaan, organisasian, mengerakkan, dan pengawasan yang dilakukan untuk menentukan serta mencapai sasaransasaran yang telah ditetapkan melalui pemanfaatan sumber daya manusia serta sumber-sumber lainnya untuk mencapai tujuan tertentu (Danim, 2010:18)".

Berdasarkan pendapat diatas dapat diambil makna bawah manajemen mengandung arti optimalisasi sumbersumber daya atau pengelolaan dan pengendalian. Sumber-sumber daya yang optimal, dikelola dan dikendalikan tersebut meliputi sumber daya manusia dan sumber pendukung lainnya. Proses tersebut mencakup lngkah-langkah perencanaan, organisasian, pelaksanakan dan pengendalian .

\section{B. Manaajemen Summber Dayya Mannusia}

Manajemen sumber daya manusia (MSDM) merupakan satu bidang dari manajemen umum yang meliputi segi-segi perencanaan, pengorganisasian, pelaksanaan dan pengendalian. Proses ini terdapat dalam fungsi/bidang produksi, pemasaran, keuangan maupun kepegawaian. Karena SDM dianggap semakin penting perannya dalam pencapaian tujuan perusahaan, maka berbagai pengalaman dan hasil penelitian dalam bidang SDM dikumpulkan secara sistematis dalam apa yang disebut manajemen sumber daya manusia. Istilah manajemen mempunyai arti sebagai kumpulan pengetahuan tentang bagaimana seharusnya memanage (mengelola) sumberdaya manusia.

Berikut ini dikemukakan beberapa definisi mengenai pengertian manajemen sumber daya manusia. Menurut Hasibuan (2017:10) "Manajemen sumber daya manusia adalah ilmu dan seni mengatur hubungan dan peran tenaga kerja agar efektif dan efisien membantu terwujudnya tujuan perusahaan, karyawan, dan masyarakat." Menurut Flippo dalam Hasibuan (2017:11) manajemen sumber daya manusia adalah "proses perencanaan, pengorganisasian, pengarahan dan pengawasan kegiatan-kegiatan pengadaan, pengembangan, pemberian kompensasi, pengintegrasian, pemeliharaan dan pelepasan sumber daya manusia agar tercapai tujuan yang diinginkan".

Sedangkan menurut Mangkunegara (2015:2) manajemen sumber daya manusia merupakan suatu perencanaan, pengorganisasian, pengkoordinasian, pelaksanaan, dan pengawasan terhadap pengadaan, pengembangan, pemberian balas jasa, pengintegrasian, pemeliharaan, dan pemisahan tenaga kerja dalam rangka mencapai tujuan organisasi.

Dari uraian definisi-definisi diatas, dapat ditarik kesimpulan bahwa manajemen sumber daya manusia adalah proses mengatur dan mengelola sumber daya manusia dan pemanfaatannya untuk mencapai tujuan organisasi dengan mengembangkan kemampuan, memotivasi, dan mempertahankan komitmen mereka terhadap organisasi.

Adapun fungsi-fungsi manajemen SDM menurut Rivai (2015:13) yaitu:

1. Fungsi Manajerial

a.Perencanaan (planning)

Perencanaan merupakan suatu kegiatan menetapkan tujuan, merumuskan dan menetapkan berbagai macam program yang menyangkut sumber daya manusia untuk membantu tercapainya tujuan.

b.Pengorganisasin (organizing)

Pengorganisasian merupakan kegiatan untuk menyusun suatu organisasi dengan mendesain struktur dan hubungan antara tugas-tugas yang harus dikerjakan oleh tenaga kerja yang dipersiapkan.

c. Pengarahan (directing)

Pengarahan merupakan suatu kegiatan untuk memberikan dorongan dan menciptakan kemauan kerja yang dilaksanakan secara efektif dan efisien.

d.Pengendalian (controlling) 
Pengawasan ditujukan agar usaha atau kegiatan untuk merealisasikan tujuan secara efektif dan efisien tidak menyimpang dari rencana yang telah ditetapkan.

2. Fungsi Operasional

a. Pengadaan tenaga kerja (SDM)

Pengadaan karyawan adalah fungsi untuk mendapatkan atau menyediakan karyawan atau sumber daya manusia sesuai dengan jumlah dan tipe yang dibutuhkan dalam rangka pencapaian tujuan organisasi.

b. Pengembangan

Fungsi pengadaan berhubungan dengan usaha atau kegiatan untuk meningkatkan keahlian dan kecakapan para karyawan atau sumber daya manusia melalui pelatihan dan pengembangan untuk mendapatkan prestasi kerja (job performance) yang sesuai.

c. Kompensasi

Kompensasi adalah kegiatan yang dilakukan perusahaan untuk mempertahankan karyawannya, dengan cara menghargai kemampuan karyawan dan memberi imbalan yang pantas kepada karyawan, sesuai dengan kontribusinya kepada perusahaan.

d. Pengintegrasian

Suatu aktivitas yang berhubungan dengan usaha utuk menyelaraskan kepentingan-kepentingan baik individu maupun kepentingan organisasi.

e. Pemeliharaan

Fungsi ini bertujuan untuk mempertahankan atau meningkatkan kondisi-kondisi yang sudah baik dalam perusahaan.

f. Pemutusan hubungan kerja

Kegiatan ini berhubungan dengan pemutusan hubungan kerja, setelah karyawan yang bersangkutan dinilai tidak sesuai dengan kebutuhan dan tujuan perusahaan.
Peranan teori manajemen sumber daya manusia dalam penelitian ini adalah sebagai induk teori dari variabel-variabel yang akan penulis teliti. Dalam teori manajemen sumber daya manusia juga mencakup teori perilaku organisasi. Sehingga keseluruhan variabel dalam penelitian ini masih satu kesatuan dalam teori manajemen sumber daya manusia.

\section{Budaya Kerja $\left(\mathbf{X}_{1}\right)$}

"Budaya kerja sudah lama dikenal oleh umat manusia, namun belum disadari bahwa suatu keberhasilan kerja itu berakar pada nilai-nilai yang dimiliki dan perilaku yang menjadi kebiasaannya.Nilai-nilai yang menjadi kebiasaan tersebut dinamakan budaya dan oleh karena budaya tersebut dikaitkan dengan mutu/kualitas kerja maka dinamakan budaya kerja.

Budaya kerja adalah "suatu falsafah dengan didasari pandangan hidup sebagai nilai-nilai yang menjadi sifat, kebiasaan dan juga pendorong yang dibudayakan dalam suatu kelompok dan tercermin dalam sikap menjadi perilaku, cita-cita, pendapat, pandangan serta tindakan yang terwujud sebagai kerja".(Supriyadi dan Triguno, $2015: 8$ ).

Adapun pengertian budaya kerja menurut Hadari Nawawi dalam bukunya Manajemen Sumber Daya Manusia menjelaskan bahwa Budaya Kerja adalah kebiasaan yang dilakukan berulang-ulang oleh pegawai dalam suatu organisasi, pelanggaraan terhadap kebiasaan ini memang tidak ada sangsi tegas, namun dari pelaku organisasi secara moral telah menyepakati bahwa kebiasaan tersebut merupakan kebiasaan yang harus ditaati dalam rangka pelaksanaan pekerjaan untuk mencapai tujuan.

Menurut Keputusan Menteri Pendayagunaan Aparatur Negara Nomor 25/KEP/M.PAN//04/2002 budaya kerja adalah "sikap dan perilaku individu dari kelompok aparatur negara yang didasari atas nilai-nilai yang diyakini 
kebenarannya dan menjadi sifat serta kebiasaan para aparatur negara dalam melaksanakan tugas dan pekerjaan seharihari".

Dari definisi-definisi di atas, dapat disimpulkan bahwa budaya kerja merupakan sikap, perilaku dan cara pandang individu dari kelompok anggota organisasi dalam bekerja. Kesadaran dalam melakukan aktivitas pekerjaan tersebut didasari atas nilai-nilai yang diyakini oleh para anggota organisasi kebenarannya dan hal tersebut menjadi sifat serta kebiasaan para anggota organisasi dalam melaksanakan tugas dan pekerjaan sehari-hari untuk mewujudkan prestasi kerja terbaik.

\section{Pelatihan $\left(\mathbf{X}_{2}\right)$}

\section{Pengertian Pelatihan}

Pelatihan menurut Dessler (2018:280) adalah proses mengajarkan karyawan baru atau yang ada sekarang, ketrampilan dasar yang mereka butuhkan untuk menjalankan pekerjaan mereka. Pelatihan merupakan salah satu usaha dalam meningkatkan mutu sumber daya manusia dalam dunia kerja. Karyawan, baik yang baru ataupun yang sudah bekerja perlu mengikuti pelatihan karena adanya tuntutan pekerjaan yang dapat berubah akibat perubahan lingkungan kerja, strategi, dan lain sebagainya.

Kemudian menurut Andrew Sikula dalam Mangkunegara (2015:44) pelatihan adalah suatu proses pendidikan jangka pendek yang mempergunakan prosedur sistematis dan terorganisir dimana pegawai non managerial mempelajari pengetahuan dan keterampilan teknis dalam tujuan terbatas.

2. Manfaat Pelatihan

Manfaat pelatihan pada dasarnya untuk meningkatkan kemampuan karyawan dalam pekerjaannya. Adapun menurut Veithzal Rivai (2015:167) manfaat pelatihan tersebut diantaranya: a. Manfaat bagi karyawan

1) Membantu karyawan dalam membuat keputusan dan pemecahan masalah yang lebih efektif.

2) Memberikan informasi tentang meningkatnya pengetahuan kepemimpinan, keterampilan komunikasi dan sikap.

3) Melalui pelatihan dan pengembangan, variabel pengenalan, pencapaian prestasi, pertumbuhan, tanggung jawab dan kemajuan dapat diinternalisasi dan dilaksanakan.

4) Membantu karyawan mengatasi stres, tekanan, frustasi, dan konflik.

5) Meningkatkan kepuasan kerja dan pengakuan.

6) Memenuhi kebutuhan personal peserta dan pelatihan.

7) Memberikan nasihat dan jalan untuk pertumbuhan masa depan.

8) Membantu karyawan mendekati tujuan pribadi sementara meningkatkan keterampilan interaksi.

9) Membangun rasa pertumbuhan dalam pelatihan.

10) Membantu pengembangan keterampilan mendengar, bicara dan menulis dengan latihan.

11) Membantu menghilangkan rasa takut melaksanakan tugas baru.

b. Manfaat bagi perusahaan

1) Mengarahkan untuk meningkatkan profitabilitas atau sikap yang lebih positif terhadap orientasi profit.

2) Memperbaiki pengetahuan kerja dan keahlian pada semua level perusahaan.

3) Memperbaiki moral SDM.

4) Membantu karyawan untuk mengetahui tujuan perusahaan.

5) Membantu menciptakan image perusahaan yang lebih baik. 
6) Mendukung otentisitas, keterbukaan dan kepercayaan.

7) Meningkatkan hubungan antara atasan dan bawahan.

\section{E. Kinerja Karyawan (Y)}

Kinerja merupakan tingkat produktivitas seorang karyawan, relatif kepada rakan sekerja, mengenai beberapa keputusan dan tingkah laku yang berkaitan dengan tugas itu. Kinerja dipengaruhi oleh variabel yang terkait dengan pekerjaan meliputi role-stress dan konflik kerja / non-kerja (Riani, 2013:61).

Definisi mengenai pengertian kinerja dapat kita ambil dari kamus bahasa Indonesia yang diartikan sebagai sesuatu yang dicapai, prestasi yang diperlihatkan dari kemampuan kerja.

Menurut Wirawan (2009:5) kinerja adalah "hasil pelaksanaan pekerjaan, baik berupa fisik atau material maupun non material pekerja dalam melaksanakan tugas-tugasnya sebagaimana terdapat di deskripsi pekerjaan atau jabatan, perlu dinilai setelah tenggang waktu tertentu".

"Kinerja adalah penampilan hasil karya personel baik kuantitas maupun kualitas dalam suatu organisasi". (Ilyas, 2002:65). Kinerja merupakan "perilaku nyata yang ditampilkan setiap orang sebagai prestasi kerja yang dihasilkan oleh karyawan sesuai denga perannya dalam perusahaan.Kinerja karyawan merupakan suatu hal yang sangat penting dalam upaya pengetahuan untuk mencapai tujuannya". (Rivai, 2006 : 309).

Dari beberapa pendapat diatas maka dapat ditarik kesimpulan bahwa kinerja adalah sebuah aksi bukan sebuah kejadian.Kinerja adalah hasil kerja secara kualitas dan kuantitas yang dicapai oleh seorang karyawan bekerja untuk periode waktu tertentu.

\section{F. Hipotesis Penelitian}

Hipotesis yang diuji dalam penelitian ini berkaitan dengan ada atau tidaknya pengaruh yaang signifikan dari seperangkat pembolehubah bebas kepada pemboleh ubah bergantung. Adapan hipotesis yang diuji yakni sebagai berikut:

1. $\mathrm{H}_{\mathrm{o}}$ : variiabel budaya kerja tidak berpengaruh secara parsial terhadap kinerja karyawan.

$\mathrm{H}_{\mathrm{a}}$ : variabel budaya kerja berpengaruh secara parsial terhadap kinerja karyawan.

2. $\mathrm{H}_{\mathrm{o}}$ : variabel pelatihan tidak berpengaruh secara parsial terhadap kiinerja karyawan.

$\mathrm{H}_{\mathrm{a}}$ : variabel pelatihan berpengaruh secara parsial terhadap kinnerja karyawan.

3. $\mathrm{H}_{\mathrm{o}}$ : variabel budaya kerja dan pelatihan tidak berpengaruh secara simultan terhadap kineja karyawan.

$\mathrm{H}_{\mathrm{a}}$ : variabel budaya kerja dan pelatihan berpengaruh secara simultan terhadap kineja karyawan.

\section{METODE PENELITIAN}

Penelitian dilakukan pada PT. Blue Bird di Poll Jakarta Timur Metode yang digunakan dalam penelitian ini adalah metode kuantitatif. Dengan menggunakan metode analisis regresi linier berganda. Populasi sasaran dalaam penelitian ini adalah karyawan yang bekerja di PT. Blue Bird Pool Jakarta Timur sebanyak 60 orang yang bekerja di PT. Blue Bird Pool Jakarta Timur. Sampel yang penulis masukkan dalam penelitian adalah sebanyak 60 orang karyawan dengan menggunakan sampel Jenuh. Pengumpulan data dilakukan dengan cara dokumentasi, wawancara dan kuesioner.

\section{HASIL DANN PEMBAHASAN}

\section{A. Gambaran Objek Penelitian}

Dari taksi, kontainer dan alat berat, hingga logistik, Blue Bird Group adalah kelompok usaha yang siap melayani segala kebutuhan Anda. Bagi banyak warga Jakarta dan kota-kota besar di 
Indonesia, Blue Bird Group bukan hanya sekadar perusahaan taksi tapi menjadi bagian dari gaya hidup. Jika New York terkenal dengan yellow taxi dan London dengan black cab, maka Jakarta dengan Blue Bird yang merupakan armada taksi biru yang selalu menghiasi jalan-jalan Ibukota yang sibuk setiap waktu (http://www.bluebirdgroup.com).

Dengan terus melayani jutaan penumpang setiap bulannya, Blue Bird Group telah memperluas jenis layanannya, mulai dari regular taxis (Blue Bird \& Pusaka) sampai dengan executive taxi (Silver Bird), limousine dan car rental (Golden Bird), charter bus (Big Bird), Logistic (Iron Bird Logistic), Industry (Restu Ibu Pusaka-Bus Body Manufacturing \& Pusaka Niaga Indonesia), Properti (Holiday Resort Lombok dan Pusaka Bumi Mutiara), IT dan Supporting Services (Hermis Consulting-IT SAP, Pusaka Integrasi Mandiri-EDC, Pusaka GPS, Pusaka Buana Utama-Petrol Station, Pusaka Bersatu-Lubricant, Pusaka Sukucadang Indonesia-Spare Part) dan Heavy Equipment (Pusaka Andalan Perkasa dan Pusaka Bumi Transportasi). (http://www.bluebirdgroup.com).

Kami berkomitmen untuk terus menjaga kualitas pelayanan dalam setiap bisnis yang kami jalani. Misalnya, strategi penempatan armada serta kemudahan mendapatkannya, telah membuat salah satu anak perusahan kami, PT Blue Bird Tbk meraih predikat sebagai mitra transportasi yang handal dan terpercaya. Kini layanan Blue Bird Group dapat dinikmati termasuk Jakarta dan sekitarnya, Bali, Bandung, Banten, Batam, Lombok, Manado, Medan, Padang, Pekanbaru, Palembang, Semarang, Solo, Surabaya dan Yogyakarta. Juga di jantung pusat bisnis dan tujuan wisata di seluruh negeri (http://www.bluebirdgroup.com).

\section{B. Analisis dan Pembahasan}

\section{Hassil Ujii Valiiditas}

Kesahan adalah ukuran yang menunjukkan sejauh mana alat ukur dapat mengukur apa yang diukur. Menurut Ghozali (2013:52) ujian kesahihan digunakan untuk mengukur kesahihan atau kesahihan kuesioner. Berikut ialah keputusan ujian kesahihan:

Tabel 1

Hasil Uji Validitas

\begin{tabular}{|c|c|c|c|}
\hline Butir & $\begin{array}{c}\text { Corrected Item- } \\
\text { Total Correlation }\end{array}$ & Ptabel & Keterangan \\
\hline \multicolumn{4}{|c|}{ Budaya Kerja $\left(\mathbf{X}_{1}\right)$} \\
\hline BK1 & 0,823 & 0,254 & Valid \\
\hline BK2 & 0,578 & 0,254 & Valid \\
\hline $\mathrm{BK} 3$ & 0,478 & 0,254 & Valid \\
\hline BK4 & 0,742 & 0,254 & Valid \\
\hline BK5 & 0,601 & 0,254 & Valid \\
\hline BK6 & 0,511 & 0,254 & Valid \\
\hline BK7 & 0,830 & 0,254 & Valid \\
\hline BK8 & 0,550 & 0,254 & Valid \\
\hline \multicolumn{4}{|c|}{ Pelatihan $\left(\mathrm{X}_{2}\right)$} \\
\hline PL1 & 0,719 & 0,254 & Valid \\
\hline PL2 & 0,670 & 0,254 & Valid \\
\hline PL3 & 0,509 & 0,254 & Valid \\
\hline PL4 & 0,540 & 0,254 & Valid \\
\hline PL5 & 0,737 & 0,254 & Valid \\
\hline PL6 & 0,682 & 0,254 & Valid \\
\hline PL7 & 0,770 & 0,254 & Valid \\
\hline PL8 & 0,728 & 0,254 & Valid \\
\hline PL9 & 0,677 & 0,254 & Valid \\
\hline PL10 & 0,737 & 0,254 & Valid \\
\hline PL11 & 0,682 & 0,254 & Valid \\
\hline \multicolumn{4}{|c|}{ Kinerja Karvawan (Y) } \\
\hline KK1 & 0,807 & 0,254 & Valid \\
\hline KK2 & 0,602 & 0,254 & Valid \\
\hline KK3 & 0,642 & 0,254 & Valid \\
\hline KK4 & 0,450 & 0,254 & Valid \\
\hline KK5 & 0,442 & 0,254 & Valid \\
\hline KK6 & 0,680 & 0,254 & Valid \\
\hline KK7 & 0,703 & 0,254 & Valid \\
\hline
\end{tabular}

Dari hasil uji validitas tersebut, diperoleh data yang menyatakan bahwa dari item pertanyaan yang diberikan kepada 60 responden ditemukan nilai Corrected Item-Total Correlation ( $\left.\mathrm{r}_{\text {tabel }}\right)$ lebih besar dari nilai 0,254 ( $\left.\mathrm{r}_{\text {tabel }}\right)$ yang berarti valid maka dapat dilanjutkan ke penelitian berikutnya.

\section{Hasil Uji Reliabilitas}

Ujian kebolehpercayaan ini digunakan untuk menguji konsistensi data dalam tempoh masa tertentu, iaitu untuk menentukan sejauh mana pengukuran yang digunakan boleh dipercaya atau dipercayai. Pembolehubah alpha cronbach dikatakan mempunyai nilai yang lebih 
besar daripada 0.70 yang bermaksud bahawa instrumen tersebut boleh digunakan sebagai pengumpul data yang boleh dipercayai, yang merupakan hasil pekali pengukuran relatif jika pengukuran berulang dibuat. Ujian kebolehpercayaan ini bertujuan untuk melihat konsistensi (Ghozali, 2013: 48). Berikut ialah keputusan ujian kebolehpercayaan:

Tabel 2

Hasil Uji Reliabilitas

\begin{tabular}{|l|c|c|c|}
\hline \multicolumn{1}{|c|}{ Variabel } & Cronbach's Alpha & NOf Iten & Keterangan \\
\hline BudayaKeria $\left(X_{1}\right)$ & 0,876 & 8 & Reliabel \\
\hline Pelathan $\left(X_{2}\right)$ & 0,918 & 11 & Reliabel \\
\hline Kineina Karyayran $(Y)$ & 0,855 & 7 & Reliabel \\
\hline
\end{tabular}

Berdasarkan jadual di atas, dapat dilihat bahwa pembolehubah yang terdiri dari budaya kerja dan pelatihan mempunyai data yang dapat diandalkan, ini dapat dilihat dari nilai alpha cronbach lebih besar dari 0.70. Ini membuktikan bahawa kajian ini dapat diteruskan .

\section{Hasil Uji Asumsi Klasik}

\section{a. Hasil Uji Normalitas}

Ujian normalisasi bertujuan sama ada dalam model regresi pembolehubah bergantung (bebas) dan pembolehubah bebas (bebas) mempunyai sumbangan atau tidak (Ghozali, 2013: 147). Berikut adalah hasil ujian normal:

1) Analisis Grafik

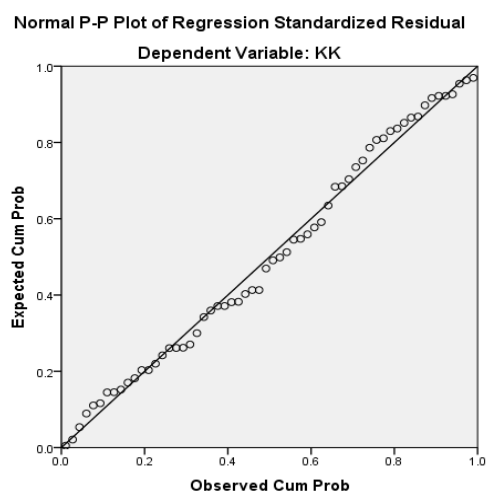

Ga mbar 1

Has il U ji Nor malitas Da ta (S ecara G rafik)
Pada grafik normal plot menunjukkan titik tersebar di sekitar garis pepenjuru, dan penyebaran mengikuti arah garis pepenjuru. Kedua-dua graf ini menunjukkan bahawa model regresi adalah mungkin kerana andaian normal (Ghozali 2013: 163) .

2) Analisis Statistik

Selain dengan analisis grafik maka perlu dianjurkan dengan uji statistik, agar mencapai ketepatan yang lebih baik. Ujian normalisasi statistik boleh dilihat berdasarkan ujian smyrnov kolmogorof, adapun pengujianya adalah sebagai berikut:

\section{T abel 3}

\section{$\mathrm{H}$ asil U ji Normalitas Data} (Secara Statistik)

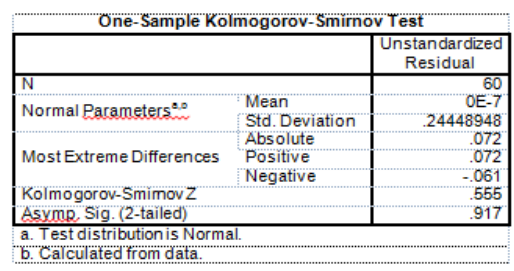

Berdasarkan ujian KolmogorovSmirnov, dapat dilihat nilai sisa yang tidak mempunyai nilai Asymp. Sig. > 0.05, ini bermakna data diedarkan secara normal.

\section{b. Hasil U ji Multikoolinearitas}

Tabel 4

Hasil Uji Multikoolinearitas

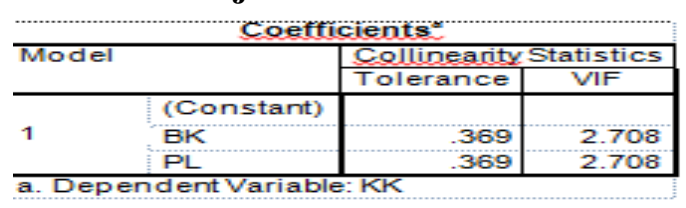

Berdasarkan jadual di atas, dapat dilihat bahawa nilai Toleransi tidak kurang daripada 0.1 dan Nilai Faktor Inflasi Variasi (VIF) tidak lebih dari 10, analisis ini dapat disimpulkan bahawa model regresi berganda linear bebas dari anggapan klasik, sehingga pembolehubah dapat digunakan dalam penyelidikan .

\section{c. H asil $\mathrm{U}$ ji Heteroskesdastisitas}




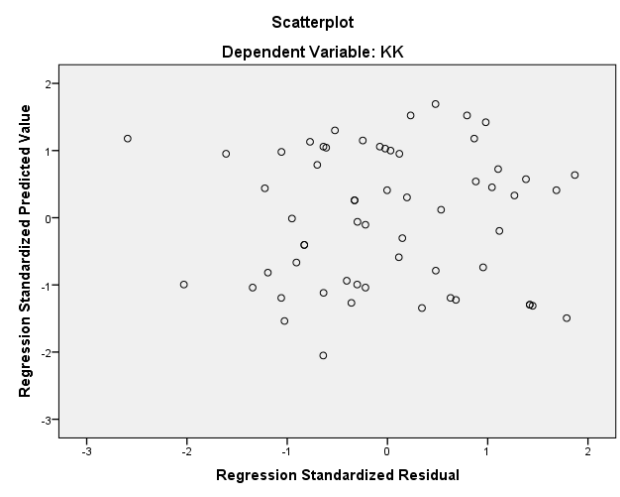

Gambar 2

Hasil Uji Heteroskedastisitas

Dari graf Scatterplot dalam gambar di atas, dapat dilihat bahawa titik-titik itu tersebar secara rawak, dan menyebarkan kedua-duanya di atas dan di bawah sifar pada paksi Y. Dapat disimpulkan bahawa tidak ada heteroscedasticity dalam model regresi. (Ghozali 2013: 139).

\section{Haasil Ujii Hiipotesis Peneelitian}

a. Has il U ji t (H asil U ji Se cara Parsi al)

Ujian separa hipotesis ini bertujuan untuk menentukan sama ada terdapat pengaruh separa pembolehubah bebas pada pemboleh ubah bergantung. Hasil hipotesis dalam ujian ini adalah seperti berikut:

\section{Ta bel 5}

Ha sil U ji t (Par sial)

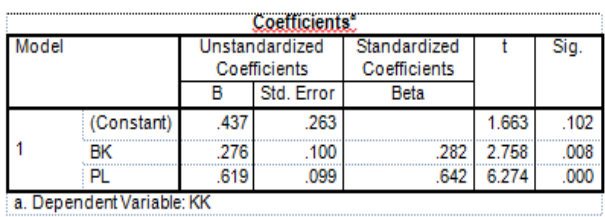

Berdasarkan data di atas, dapat dilihat bahawa secara parsial budaya kerja mempunyai kesan yang signifikan terhadap kinerja karyawan dan secara parsial pelatihan memiliki pengaruh terhadap kinerja karyawan.

\section{b. Hasil Uji Simultan F}

Tabel 6

Hasil Uji t (Parsial)

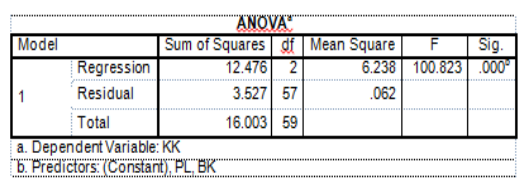

Dalam jadual analisis varians (Anova), keputusan ujian $\mathrm{F}$ dipaparkan yang dapat digunakan untuk meramalkan sumbangan aspek budaya kerja dan pelatihan kepada pemboleh ubah kinerja karyawan. Daripada pengiraan, nilai $F$ yang dikira adalah 100,823 . Dengan tahap penting $5 \%$ dan df $1=2$ dan df $2==57$, nilai $\mathrm{F}_{\text {table }}=3,16$ diperolehi. Oleh kerana nilai Fcount $(100,823)>$ nilai jadual $F$ $(3,16)$, dapat disimpulkan bahawa dua pembolehubah bebas iaitu budaya kerja dan pelatihan menyumbang secara signifikan kepada pemboleh ubah kinerja karayawan. Sehingga model regresi yang diperoleh sesuai untuk digunakan untuk meramalkan. Kemudian dapat disimpulkan bahwa $\mathrm{H}_{\mathrm{o}}$ ditolak dan $\mathrm{H}_{\mathrm{a}}$ diterima.

\section{Hasil Koefisien Persamaan Regresi Linier Berganda}

\section{Tabel 7}

\section{Hasil Koefisisen Regresi Linier}

\begin{tabular}{|c|c|c|c|c|c|c|}
\hline \multirow{3}{*}{ Mode } & & & Coefficien & & & \\
\hline & & \multicolumn{2}{|c|}{$\begin{array}{l}\text { Unstandardized } \\
\text { Coefficients }\end{array}$} & \multirow{2}{*}{$\begin{array}{c}\text { Standardized } \\
\text { Coefficients } \\
\text { Beta } \\
\end{array}$} & \multirow[t]{2}{*}{$\mathrm{t}$} & \multirow{2}{*}{ Sig. } \\
\hline & & $B$ & Std. Error & & & \\
\hline \multirow{3}{*}{1} & (Constant) & .437 & .263 & & 1.663 & .102 \\
\hline & BK & 276 & .100 & 282 & 2.758 & .008 \\
\hline & PL & 619 & .099 & 642 & 6.274 & .000 \\
\hline
\end{tabular}

Berdasarkan hasil yang diperoleh dari pekali regresi di atas, persamaan regresi boleh dibuat seperti berikut:

$Y=0,437+0,276 X_{1}+0,619 X_{2}$

Dalam persamaan regresi di atas menunjukkan nilai tetap 0,437. Ini menyatakan bahawa jika budaya kerja dan pelatihan pembolehubah dianggap malar atau bernilai 0 (sifar), maka kinerja karyawan akan meningkat sebanyak 0,437 .

Pekali regresi pada pemboleh ubah budaya kerja adalah 0,276, ini bermakna jika pembolehubah budaya kerja meningkat satu unit maka pemboleh ubah kinerja karyawan akan meningkat 
sebanyak 0,276. Perhatikan bahawa pembolehubah lain dianggap malar.

Pekali regresi pada pemboleh ubah pelatihan adalah 0,619 , ini bermakna jika pemboleh ubah pelatihan meningkat satu unit maka kinerja karyawan berubah-ubah akan meningkat sebanyak 0,619. Perhatikan bahawa pembolehubah lain dianggap malar.

\section{Hasil Koefisien Determinasi $\left(R^{2}\right)$}

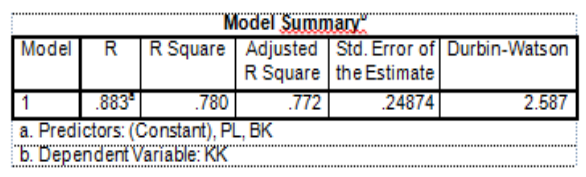

Dari tabel di atas dapat diketahui koefisien determinasi (R Square) sebesar 0,780 atau $78,0 \%$. Hasil tersebut memberi pengertian bahwa vaiabel dependen yaitu kinerja pegawai dapat dijelaskan oleh variabel independen yang terdiri dari budaya kerja dan pelatihan dengan nilai sebesar $78,0 \%$ sedangkan sisanya $22 \%$ dijelaskan oleh variabel independen lainnya yang tidak dimasukkan dalam model penelitian ini.

\section{KESIMPULAN DAN SARAN}

\section{A. Kesimpulan}

Berdasarkan hasil penyelidikan dan analisis yang dijelaskan dalam bab sebelumnya oleh penulis tentang pengaruh budaya kerja dan pelatihan terhadap kinerja karyawan di PT. Blue Bird Pool Jakarta Timur, dapat disimpulkan oleh para peneliti, yaitu:

1. Berdasarkan keputusan ujian $t$ (sebahagian) didapati budaya kerja mempengaruhi terhadap kinerja karyawan.

2. Berdasarkan hasil uji t (parsial) ditemukan bahwa pelatihan berpengaruh terhadap kinerja karyawan.

3. Berdasarkan keputusan ujian F (serentak) didapati budaya kerja dan pelatihan mempengaruhi kinerja karyawan

\section{B. Saran}

Dalam sebuah organisasi, peranan dan kendali sumber daya manusia sangat penting dalam pencapaian tujuan yang diinginkan. Pegawai yang memiliki kinerja baik dalam menjalankan pekerjaan tentu perlu diperhatikan dan dipertahankan. Dengan adanya para pegawai yang memiliki kinerja yang sesuai dengan harapan dan tujuan sebuah organisasi, serta pegawai yang berkualitas dan profesional dapat meningkatkan citra dan kualitas organisasi tersebut.

Peningkatan kinerja pegawai tentu tidak terlepas dari berbagai faktor yang mempengaruhi, seperti dalam penelitian ini setidaknya ada dua faktor yang secara signifikan mempengaruhi kinerja pegawai yakni budaya kerja dan pelatihan. Kedua faktor tersebut mempengaruhi kinerja baik secara parsial maupun simultan.

Hasil penelitian ini menunjukkan bahwa budaya kerja dan pelatihan secara signifikan mempengaruhi kinerja pegawai di PT. Blue Bird Pool Jakarta Timur, Terkait hasil penelitian ini maka kinerja pegawai dapat ditingkatkan melalui peningkatan dalam hal penerapan budaya kerja dan pelatihan.

\section{DAFTAR PUSTAKA}

Dessler, Gary. 2015. Manajemen Sumber Daya Manusia. Jakarta: Salemba Empat.

Ghozali, Imam. 2005. Aplikasi Analisis Multivariate dengan SPSS. Semarang: Badan Penerbit UNDIP.

Hamid, Abdul. 2010. Panduan Penulisan Skripsi. Jakarta: FEIS UIN Press.

Hasibuan, Malayu SP. 2017. Manajemen Sumber Daya Manusia. Bandung: Bumi Aksara.

Ilyas, Jaslis. 2002. Kinerja: Teori, Penilaian dan Penelitian. Depok: Pusat Kajian Ekonomi FKMUI

Krisnaldy, K., Pasaribu, V. L. D., \& Senen, S. (2019). PENGARUH BUDAYA 
JRNAL ПMாAH

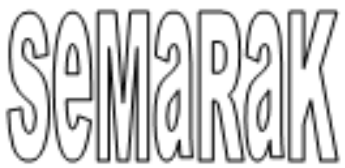

P-ISSN 2615-6849, E-ISSN 2622-3686

Jurnal Semarak,Vol. 3,No.2, JUNI 2020, Hal (53- 65)

@Prodi Manajemen Fakultas Ekonomi Universitas Pamulang

\author{
ORGANISASI, LINGKUNGAN \\ KERJA DAN IKLIM \\ ORGANISASI TERHADAP \\ MOTIVASI PEGAWAI SERTA \\ DAMPAKNYA TERHADAP \\ KEPUASAN KERJA. Jurnal \\ Semarak, 2(2).
}

Mangkunegara, Anwar Prabu. 2015. Manajemen Sumber Daya Manusia Perusahaan. Bandung: Remaja Rosdakarya.

Pasaribu, V. L. D., \& Krisnaldy, K. (2018). ANALISIS KEPUASAN JAMA'AH PADA KINERJA DEWAN KEMAKMURAN MASJID ALHIDAYAH PERIODE TAHUN 2017. KREATIF: Jurnal Ilmiah Prodi Manajemen Universitas Pamulang, 6(4), 41-51.

Pasaribu, V. L. D., Krisnaldy, K., \& Warasto, H. N. (2020). Pengaruh Gaya Kepemimpinan, Disiplin Kerja Dan Kompensasi Terhadap Kinerja Pegawai (Studi kasus kelurahan Pisangan Ciputat). Jurnal Disrupsi Bisnis: Jurnal Ilmiah Prodi Manajemen, Fakultas Ekonomi, Universitas Pamulang, 3(1).

Rivai, Veithzal. 2015. Manajemen Sumber Daya Manusia untuk Perusahaan. Depok: Rajawali Pers.

Robbins, Stephen P. 2014. Perilaku Organisasi (Organizational Behaviour). Jakarta: Salemba Empat.

Robbins, Stephen P dan Mary Coulter. 2012. Manajemen. Jakarta: Erlangga.

Sedarmayanti. 2011. Manajemen Sumber Daya Manusia, Reformasi Birokrasi dan Manajemen Pegawai Negeri Sipil. Bandung: Refika Aditama.
Supriyadi, Gering dan Triguno. 2001. Budaya Kerja Organisasi Pemerintah. Jakarta.

Thoha, Miftah. 2015. Perilaku Organisasi: Konsep Dasar dan Aplikasinya. Depok: Rajawali Pers.

Wirawan. (2009). Evaluasi Kinerja Sumber Daya Manusia Teori Aplikasi dan Penelitian. Jakarta. Penerbit: Salemba Empat.

Tjahjono, Binawan Nur dan Tri Gunarsih. 2012. Pengaruh Motivasi Kerja Dan Budaya Organisasi Terhadap Kinerja pegawai Di Lingkungandinas Bina Marga Propinsi Jawa Tengah. Jurnal Nasional.

Triasmoko, Deni. 2014. Pengaruh Pelatihan Kerja Terhadap Kinerja Karyawan PT Pos Indonesia Cabang Kota Kediri. Jurnal Nasional.

Mora, Zulkarnaen dan Muhammad Riza. 2016. Pengaruh Budaya Organisasi, Pelatihan Dan Pengembangan Terhadap Prestasi Kerja Karyawan Pada BPRS ADECO Langsa. Jurnal Nasional.

Rokhman, Wahibur dan Amirul Fatihin. 2014. Pengaruh Pelatihan dan Budaya Organisasi Terhadap Efektivitas Kinerja Karyawan di Lembaga Keuangan Mikro Syariah Kabupaten Kudus. Jurnal Nasional.

Sugiarti dkk. 2016. Pengaruh Pelatihan Kerja Terhadap Kinerja Karyawan Pada PT Padma Ardya Aktuaria Jakarta. Jurnal Nasional. 